\title{
PERANCANGAN MODEL EVALUASI DIRI DOSEN
}

\author{
Agustina Tutik $^{1}$; Synthia Atas Sari ${ }^{2}$; Hartiwi Prabowo ${ }^{3}$
}

\begin{abstract}
Article present lecturer self evaluation model as complement for IKAD (Lecturer Performance Academic Index). This research used action research analysis and technique of data collecting by library research, discussion by lecturer from any faculty and major, preview the duty and obligation of UBiNus lecturer. Variables and wight for this model are learning (30\%), professionalism (20\%), research (20\%), technology and computer (15\%), team work (10\%), and services to University (5\%)
\end{abstract}

Keywords: lecturer, self evaluation

\section{ABSTRAK}

Artikel menunjukkan suatu model evaluasi diri dosen sebagai pelengkap IKAD (Indeks Kinerja Akademik Dosen). Penelitian menggunakan analisis action research dan teknik pengumpulan data dengan studi pustaka, diskusi dengan dosen dari berbagai fakultas dan jurusan, serta penelaah kembali tugas dan kewajiban dosen UBiNus. Variabel dan bobot model evaluasi diri dosen adalah pembelajaran (bobot 30\%), profesionalisme (bobot 20\%), penelitian (bobot 20\%), teknologi dan komputerisasi (bobot 15\%), kerjasama dalam tim (bobot 10\%) dan pelayanan pada Universitas (bobot $5 \%)$.

Kata kunci: dosen, evaluasi diri

1, 2, 3 Staf Pengajar Fakultas Ekonomi Jurusan Manajemen, UBiNus, Jakarta 


\section{PENDAHULUAN}

Peningkatan mutu sebuah perguruan tinggi saat ini tidak terlepas dari peningkatan mutu para dosen sebagai sosok manusia yang paling dekat mendampingi seorang mahasiswa belajar. Hal itu diperkuat oleh pendapat Suryabrata dalam buku psikologi Pendidikan yang mengatakan bahwa salah satu faktor yang mempengaruhi belajar seseorang adalah faktor sosial, yaitu faktor manusia, baik manusia itu ada (hadir) maupun tidak hadir. Sebagai bagian sumber daya manusia dalam sebuah lembaga pendidikan, seorang dosen termasuk kelompok karyawan yang tentu saja juga akan dinilai kinerjanya.

Pengukuran indeks kinerja dosen sebagai salah satu kriteria mutu telah menjadi salah satu indikator penting bagi Universitas Bina Nusantara, tepatnya setelah Universitas Bina Nusantara menerapkan Sistem Manajemen Mutu ISO 9001 di tahun 1997. Pengukuran indeks ini dituangkan dalam bentuk angka IKAD (Indeks Kinerja Akademik Dosen) yang saat ini sudah menjadi istilah yang diadopsi juga oleh beberapa perguruan tinggi lain.

Banyak pertentangan yang muncul pada saat kinerja seorang dosen hanya diukur oleh mahasiswa yang dalam tanda petik disebut sebagai pelanggan langsung para dosen dalam memberikan jasa mereka. Bina Nusantara kemudian menambahkan juga elemen penilaian dari sisi kinerja administratif seorang dosen, seperti ketepatan penyerahan soal, persentasi kehadiran mengajar, dan sebagainya. Namun, apakah data yang dihasilkan dan tindak lanjut yang disusun oleh para Ketua Jurusan telah dapat mendorong para dosen untuk meningkatkan kinerja ke arah kemampuan pedagogi yang benar, juga tidak dapat dipastikan, mengingat motivasi diri sangat sulit jika diharapkan datang dari luar pribadi seseorang.

Mengingat seorang dosen yang secara umum dipastikan memiliki kematangan pribadi yang baik dan objektivitas sangat diutamakan dalam pekerjaan mereka, metode evaluasi diri menjadi salah satu metode evaluasi kinerja yang dapat diterapkan. Seiring dengan munculnya ide ini, dibutuhkan adanya model yang tepat dan yang dapat memberikan masukan kepada para dosen tentang hal yang masih kurang dan perlu diperbaiki, dan penilaian ini dilakukan secara pribadi.

Berdasarkan hal tersebut, sangatlah menarik untuk melakukan penelitian lebih lanjut dan mendalam untuk menyusun model evaluasi diri yang dapat digunakan bagi para dosen untuk mendapatkan gambaran kinerja mereka yang sebenarnya. Walaupun model yang akan dibentuk pasti membutuhkan keterbukaan dari objek yang dinilai, namun model itu diharapkan merupakan alat yang dapat diterima oleh para dosen untuk melakukan perbaikan. 


\section{PEMBAHASAN}

Dalam penelitian ini, masalah yang diangkat adalah faktor apa saja yang perlu dievaluasi oleh seorang dosen dalam melakukan evaluasi diri? Bagaimana model evaluasi yang dapat diterapkan di Universitas Bina Nusantara?

Penelitian ini bertujuan untuk mendapatkan variabel evaluasi diri yang dapat diterapkan untuk dosen Universitas Bina Nusantara dan mendapatkan model evaluasi yang dapat digunakan dosen dalam meningkatkan kualitas diri. Manfaat penelitian ini sebagai berikut. Pertama, untuk UbiNus, khususnya pengelola jurusan, yaitu mendapatkan mekanisme penilaian diri dosen sebagai salah satu pengukuran kinerja dosen. Kedua, untuk dosen, yaitu mendapatkan gambaran harapan universitas terhadap seorang dosen secara lebih jelas dan menanamkan budaya peningkatan terus menerus dalam diri dosen (internalisasi QA).

\section{Kerangka Pemikiran}

\section{Pengelolaan Sumber Daya Manusia}

Pengelolaan sumber daya manusia pada perguruan tinggi tidak hanya terbatas pada karyawan operasional, namun juga mencakup personel yang terlibat dalam kegiatan akademik. Hal itu berarti tujuh aktivitas dasar dalam proses manajemen SDM yang terdiri dari perencanaan rekrutmen, seleksi, sosialisasi, pelatihan dan pengembangan, penilaian prestasi kerja dan promosi, transfer, demosi, dan PHK juga terkait untuk para dosen. Dari ketujuh aktivitas dasar tersebut, semuanya saling terkait dalam sebuah sistem yang terencana baik.

\section{Penilaian Kinerja Karyawan}

Beberapa alasan sebuah organisasi melakukan penilaian kinarja menurut Dressler (2003) adalah karena penilaian kinerja memberikan peluang bagi yang menilai meninjau perilaku yang dinilai. Dalam tulisannya, Self-Evaluation of Teaching, Sorcinelli mengatakan bahwa walaupun penelitian tentang evaluasi diri ini sangat terbatas jumlahnya, namun telah menunjukkan bahwa evaluasi diri tidak dapat digunakan sebagai dasar pengambilan keputusan trhadap seseorang. Studi yang dilakukan oleh Centra, 1973; oleh Clark dan Blackburn, 1973 juga menunjukkan bahwa seorang pengajar akan secara konsisten menggunakan model evaluasi diri yang ada untuk menilai kinerjanya. Juga dikatakan bahwa penilaian ini akan memberikan data yang dapat dipercaya jika mahasiswa dan dosen melakukan penilaian menggunakan instrumen yang sama. Terlihat secara umum mereka menyetujui hasil penilaian secara keseluruhan dan beberapa dimensi pengorganisasian dan stimulasi minat. 
Metode yang diuraikan oleh Dressler merupakan metode penilaian prestasi yang menurut Soekidjo Notoatmodjo sebagai penilaian prestasi kerja berorientasi waktu lalu. Metode penilaian prestasi kerja yang berorientasi waktu akan datang, antara lain sebagai berikut. Pertama, metode penilaian diri (self appraisal), metode ini menekankan bahwa penilaian prestasi kerja karyawan dinilai oleh karyawan itu sendiri. Tujuan penilaian ini adalah untuk mengembangkan diri karyawan. Kedua, Metode Pendekatan Management by Objective (MBO). Metode penilaian ini ditentukan bersama antara penilai dengan yang dinilai. Bersama menentukan tujuan atau sasaran pelaksanaan kerja di waktu yang akan datang. Ketiga, Metode penilaian psikologis, metode penilaian mengadakan wawancara mendalam, diskusi, atau tes psikologi terhadap karyawan yang akan dinilai. Aspek yang dinilai, antara lain intelektual, emosi, motivasi karyawan yang bersangkutan. Keempat, Metode Teknik Pusat Penilaian, dalam organisasi yang sudah maju, terdapat pusat penilaian karyawan. Pusat itu mengembangkan sistem penilaian baku yang digunakan untuk menilai para karyawan. Hasil penilaian pusat ini sangat bermanfaat untuk mengidentifikasikan kemampuan manajemen di waktu mendatang.

\section{Proses Penilaian Prestasi Kerja Karyawan}

Faktor yang perlu diperhatikan dalam penyusunan standar prestasi adalah sebagai berikut. Pertama, Daftar kegiatan; penilaian prestasi sering kali didahului dengan penyusunan daftar kegiatan yang dilaksanakan. Tujuannya untuk memastikan bahwa kita tetap fokus pada prestasi dan memastikan bahwa tidak mengabaikan bagian tugas yang penting. Kedua, menetapkan apa yang akan diukur. Dari daftar kegiatan, penilai telah memilih sejumlah kegiatan yang paling penting bagi pelaksanaan tugas. Organisasi menetapkan cara mengukur pelaksanaan kegiatan tersebut. Cara pengukuran dapat dilakukan dengan pengukuran kuantitatif, pengukuran kualitatif, dan pengukuran ketepatan waktu. Penggabungan dari ketiga pengukuran itu akan sangat membantu penilai dalam memutuskan cara penilaian duatu kegiatan.

Ketiga, menetapkan kegiatan terpenting. Tidak ada sistem penilaian yang dapat mengukur semua kemungkinan prestasi kerja. Oleh karena itu, perlu memilih beberapa bagian pekerjaan yang paling penting sebagai dasar sistem evaluasi prestasi kerja karyawan. Keempat, emetapkan kualitas standar. Alat ukur penilaian prestasi harus dapat memastikan bahwa penilai bersikap jujur dan akurat dalam menilai prestasi kerja, terutama untuk alat yang digunakan untuk metode penilaian diri. Beberapa kriteria yang harus dipenuhi oleh alat ukur penilaian prestasi ini adalah dapat diukur: ukuran ini perlu disepakati oleh pihak penilai dan pihak yang dinilai; Dapat dicapai:ukuran harus rasional agar seseorang dapat atau mungkin mencapainya; Relevan: ukuran harus relevan dengan pekerjaan yang akan dinilai; Dapat dikendalikan: ukuran harus terkait untuk hal yang dapat dikendalikan oleh yang dinilai: Menetapkan tingkat standar: menetapkan standar ini bertujuan agar setiap orang dapat mengetahui kondisi yang diinginkan oleh organisasi. Standar ini perlu dikomunikasikan agar para karyawan menyadari bahwa mereka memerlukan standar itu. 


\section{Metode Penelitian}

Penelitian ini menggunakan pendekatan ilmu manajemen sumber daya manusia, khususnya yang terkait dengan pengelolaan penilaian kinerja (performance appraisal), metode penelitian yang digunakan adalah penelitian tindakan (action research). Action research adalah metode penelitian yang melihat tentang penilaian terhadap diri kita sendiri dan bagaimana kita dapat meningkatkan kinerja kita. Alasan memilih metode ini adalah penelitian tindakan merupakan cara yang paling praktis untuk melihat cara kerja yang sudah ada dan melihat apakah telah berjalan sesuai yang diharapkan, dan penelitian tindakan merupakan penelitian yang open ended atau tidak berujung, tidak dimulai dengan sebuah hipotesis tetapi dimulai dari sebuah ide yang dikembangkan.

\section{Objek Penelitian}

Penelitian dilakukan terhadap evaluasi diri untuk para dosen Universitas Bina Nusantara. Dalam tabel di bawah ini terlihat desain penelitian yang akan dilakukan untuk masing-masing tujuan penelitian. Khusus untuk tujuan ke-5 (T-5) merupakan rekomendasi hasil penelitian.

Tabel 1 Desain Penelitian

\begin{tabular}{|l|l|l|}
\hline \multirow{2}{*}{ Tujuan Penelitian } & \multicolumn{2}{|c|}{} \\
\cline { 2 - 3 } & Jenis Penelitian & Unit Analisis \\
\hline Mendapatkan faktor evaluasi & Deskriptif & $\begin{array}{l}\text { individu para dosen dan } \\
\text { pimpinan UbiNus }\end{array}$ \\
\hline Menyusun model evaluasi & Deskriptif & $\begin{array}{l}\text { Individu } \rightarrow \text { para dosen dan } \\
\text { pimpinan UBiNus }\end{array}$ \\
\hline
\end{tabular}

\section{Jenis Data dan Sumber Data}

\begin{tabular}{|l|l|}
\hline Jenis data & Sumber data \\
\hline Deskripsi faktor yang akan dievaluasi & $\begin{array}{l}\text { Data primer : wawancara kelompok dosen } \\
\text { Data sekunder : Studi pustaka }\end{array}$ \\
\hline Komponen dan bobot nilai & $\begin{array}{l}\text { Data primer : wawancara kelompok dosen } \\
\text { Data sekunder : Studi pustaka }\end{array}$ \\
\hline
\end{tabular}




\section{Teknik Pengumpulan Data}

Untuk mendapatkan data yang akan diolah, dalam penelitian ini dilakukan tiga teknik pengumpulan data, yaitu studi pustaka, wawancara kepada para Pengelola dan dosen yang dipilih dengan metode random sampling, dan observasi di lapangan.

\section{Metode Analisis}

Metode analisis yang dipakai dikaitkan dengan masing-masing tujuan, seperti terlihat dalam tabel di bawah ini.

\begin{tabular}{|l|l|l|}
\hline \multirow{2}{*}{ Tujuan Penelitian } & Metode Analisis \\
\cline { 2 - 3 } & Metode & Alat analisis \\
\hline $\begin{array}{l}\text { Mendapatkan faktor } \\
\text { evaluasi }\end{array}$ & Deskriptif survei & $\begin{array}{l}\text { Analisis faktor (mendapatkan } \\
\text { faktor mana yang akan } \\
\text { digunakan) }\end{array}$ \\
\hline Menyusun model evaluasi & Deskriptif survei & $\begin{array}{l}\text { Statistik deskriptif (perbandingan } \\
\text { self evaluation dan IKAD) }\end{array}$ \\
\hline
\end{tabular}

Studi pustaka dilakukan untuk mendapatkan faktor yang akan dievaluasi. Berdasarkan hal tersebut, dirancang sebuah model pengukuran. Model yang telah dipilih didiskusikan dengan berbagai kelompok pimpinan dan beberapa dosen dari berbagai fakultas dan jurusan dalam bentuk focus Group discussion. Dari hasil itu, model awal direvisi dan hasilnya didiskusikan ke pimpinan Jurusan dan Fakultas.

\section{Perkembangan Universitas Bina Nusantara}

\section{Visi Universitas Bina Nusantara}

Adapun visi yang dimiliki Universitas Bina Nusantara adalah unggul sebagai lembaga pendidikan berbasis teknologi informasi yang diterima sebagai panutan, siap berkompetisi dan beradaptasi terhadap perubahan global.

\section{Misi Universitas Bina Nusantara}

Untuk mewujudkan visi tersebut, Universitas Bina Nusantara menetapkan misi sebagai berikut. Pertama, menyelenggarakan program studi yang menunjang pengembangan dan penerapan Teknologi Informasi, kemampuan berbahasa asing, komunikasi, kepemimpinan, kemampuan berinovasi dan berwirausaha, serta berkarakter baik. Kedua, menyediakan sarana dan lingkungan yang kondusif bagi pelaksanaan kegiatan pembelajaran yang efektif dan efisien sehingga dapat menghasilkan lulusan yang trampil, kreatif, dan inovatif. 
Ketiga, menjaga keterkaitan dan relevansi seluruh kegiatan pendidikan dengan kebutuhan pembangunan sosial ekonomis dan industri secara global. Keempat, melakukan kerja sama dengan berbagai pihak, baik di dalam maupun di luar negeri, agar pengetahuan dan keterampilan yang diajarkan selalu mutakhir dan tepat guna penerapannya. Kelima, membangun komunitas BiNusian yang menganut budaya, nilai, dan etos kerja Bina Nusantara.

\section{Kebijakan Mutu}

Dalam rangka meningkatkan komitmen Universitas Bina Nusantara terhadap mutu lulusan, telah ditetapkan Kebijakan Mutu, yaitu Sebagai Perguruan Tinggi Bermutu, Universitas Bina Nusantara bertekad untuk menghasilkan lulusan yang BERKUALITAS TINGGI, BERKARAKTER BAIK, dan SIAP TERAP.

\section{Sasaran Mutu}

Sasaran Mutu Universitas Bina Nusantara adalah Minimal 90\% lulusan mendapatkan pekerjaan dalam tahun pertama setelah lulus; Minimal 80\% lulus tepat waktu; Minimal 80\% dan para dosen mendapat Indeks Kinerja Akademis Dosen lebih dari 3,0 (skala 1,0 - 4,0).

\section{Analisis dan Hasil Penelitian}

Penelitian ini menggunakan pendekatan ilmu manajemen sumber daya manusia, khususnya yang terkait dengan pengelolaan penilaian kinerja (performance appraisal), metode penelitian yang digunakan adalah penelitian tindakan (action research).

\section{Tahap Perancangan Model}

Dalam merancang model evaluasi diri dosen, peneliti harus menentukan variabel mana yang merupakan model evaluasi diri dosen. Tahap ini dilakukan dengan melihat kembali buku panduan dosen Ubinus (meliputi: visi, misi, tujuan, prosedur pelaksanaan perkuliahan di dalam ruang kelas, kelengkapan mengajar, dan lain-lain sampai dengan penilai kinerja dosen dan motivasi mahasiswa). Selain buku panduan dosen, peneliti juga memperoleh masukan dari studi pustaka buku, jurnal yang berkaitan dengan evaluasi diri, dan akhirnya peneliti melakukan wawancara dengan dosen dari berbagai fakultas dan jurusan untuk mendapatkan masukan. Dari tahapan ini kemudian peneliti mengambil variabel Evaluasi Diri Dosen seperti berikut ini. Variabel Evaluasi Diri Dosen Ubinus adalah Pembelajaran, Profesionalisme, Penelitian, Teknologi dan Komputerisasi, Kerja sama dalam tim, dan Pelayanan pada Universitas.

Variabel Pembelajaran, Profesionalisme, dan Penelitian bersumber pada peraturan DIKTI mengenai kriteria penilaian angka kredit dosen homebase disetiap universitas di Indonesia, diperoleh dari daftar kegiatan sebagai berikut: Pendidikan dan 
Pengajaran yang memiliki bobot 30\%; Penelitian yang memiliki bobot 25\%; Pengabdian pada masyarakat yang memiliki bobot maksimum 15\%; Penunjang Tridharma Perguruan Tinggi yang memiliki bobot maksimum 20\%.

Untuk variabel Teknologi dan Komputerisasi, peneliti mengambil berdasarkan visi-misi Ubinus yang menghendaki dosen mengerti dan menggunakan teknologi dan komputerisasi, baik dalam mengajar maupun mempersiapkan bahan dan menilai hasil belajar mahasiswa. Variabel Kerja sama dalam Tim dan Pelayanan Pada Universitas, peneliti memperoleh bahan acuan dari Annual Activities Evaluation (AAE) yang didiskusikan pada seminar Self Evaluation and Annual Review and Planning oleh Universitas Sydney, Australia pada tahun 2001.

\section{Pembobotan Variabel}

Setelah variabel dirumuskan, ditentukan bobot masing-masing variabel tersebut. Pembobotan itu juga dilihat dari urutan kepentingan hak dan kewajiban seorang dosen dan peneliti juga melihat pada prosedur penilaian dosen homebase oleh DIKTI. Hasil pembobotan adalah sebagai berikut: Pembelajaran, bobot 30\%; Profesionalisme, bobot 21\%; Penelitian, bobot 17\%; Teknologi dan Komputerisasi, bobot 15\%; Kerja sama dan Tim, bobot 10\%; Pelayanan pada Universitas, bobot 7\%.

\section{Penjelasan Pembobotan Variabel}

Pembobotan variabel ini menggunakan metode matriks berpasangan. Setelah pembobotan, baru ditentukan instrumen pengukuran untuk masing-masing variabel sehingga perancangan model evaluasi diri itu selesai.

\section{Skala Penilaian}

Perancangan model evaluasi diri dosen ini dibuat dalam bentuk kuesioner, dengan teknik skala Likert. Untuk variabel pembelajaran, profesionalisme, teknologi dan komputerisasi, serta kerja sama dalam tim serta pelayanan pada Universitas.

Nilai 1: $\quad$ tidak pernah melakukan semua aktivitas dalam instrumen pengukuran.

Nilai 2 : $\quad$ jarang, artinya hanya melakukan sebanyak 25\% dari 13/26 kali pertemuan proses belajar mengajar di Ubinus.

Nilai 3: $\quad$ cukup/kadang-kadang, artinya melakukan sebanyak 50\% dari 13/26 kali pertemuan proses belajar mengajar di Ubinus.

Nilai 4: $\quad$ sering, artinya melakukan sebanyak $75 \%$ dari $13 / 26$ kali pertemuan proses belajar mengajar di Ubinus.

Nilai 5: $\quad$ selalu, artinya melakukan sebanyak 100\% dari 13/26 kali pertemuan proses belajar mengajar di Ubinus. 
Untuk variabel penelitian:

Nilai 1 : tidak pernah melakukan penelitian.

Nilai 2 : jarang, artinya hanya melakukan sebanyak 1 kali penelitian dalam 1 tahun atau membimbing skripsi sebanyak 3 mahasiswa.

Nilai 3 : cukup/kadang-kadang, artinya hanya melakukan sebanyak 2 kali penelitian dalam 1 tahun atau membimbing skripsi sebanyak 6 mahasiswa.

Nilai 4 : sering, artinya hanya melakukan sebanyak 3 kali penelitian dalam 1 tahun atau membimbing skripsi sebanyak 9 mahasiswa.

Nilai 5 : selalu, artinya melakukan penelitian lebih dari 3 kali dalam setahun atau membimbing skripsi sebanyak lebih dari 10 mahasiswa.

\section{Uji Validitas dan Reliabilitas}

Uji validitas dan reliabilitas dilakukan dengan membagikan kuesioner evaluasi diri dosen kepada 23 responden. Dengan tingkat signifikan 5\% dan $\mathrm{df}=22$ dan $\mathrm{r}$ tabel $=$ 0,28 maka dari 53 instrumen, ada 5 instrumen pengukuran yang dinyatakan tidak valid. Pertama, pada Teknologi dan Komputerisasi, yaitu enggunakan fasilitas Binusmaya dalam mengajar di kelas, menggunakan fasilitas forum diskusi dalam interaksi dengan mahasiswa, menggunakan program aplikasi yang disediakan Binus, misalnya memasukkan nilai mahasiswa, dan menggunakan fasilitas home page: Lecturer.binus.ac.id dalam melihat kegiatan kuliah. Instrumen itu merupakan kemampuan yang harusnya dimiliki oleh seluruh dosen Binus. Jadi dianggap instrumen tersebut tidak perlu dinilai karena semua dosen Binus memiliki kemampuan tersebut.

Kedua, kerja sama dalam Tim, yaitu saling menghargai diantara sesama rekan kerja dan tim. Instrumen pengukuran yang tidak valid ini disebabkan ketidaksesuaian instrumen tersebut dalam model evaluasi diri dosen Binus. Selain itu, instrumen ini merupakan tindakan dasar yang seharusnya dilakukan oleh seluruh umat manusia sehingga tindakan tersebut tidak diperlukan penilaian lagi.

Dari hasil uji reliabilitas, nilai alpha yang diperoleh adalah sebesar 0,9334. Karena nilai alpha $>0,6$, instrumen pengukuran yang digunakan dinyatakan sudah reliable.

\section{Perhitungan Total Nilai Evaluasi Diri Dosen}

Penghitungan dan Pengkategorian

Keseluruhan Model Evaluasi Diri Dosen

\begin{tabular}{|c|c|c|c|c|}
\hline \multirow[b]{2}{*}{ No. } & \multirow[b]{2}{*}{ Item } & \multirow[b]{2}{*}{ Bobot } & \multicolumn{2}{|c|}{$\begin{array}{l}\text { Angka Item setelah } \\
\text { dikali dengan Bobot }\end{array}$} \\
\hline & & & Tertinggi & Terendah \\
\hline 1 & Pengajaran & $30 \%$ & 18 & 3,6 \\
\hline 2 & Profesionalisme & $21 \%$ & 13,65 & 2,73 \\
\hline
\end{tabular}




\begin{tabular}{|c|l|c|c|c|}
\hline 3 & Penelitian & $17 \%$ & 5,95 & 1,19 \\
\hline 4 & Teknologi dan Komputer & $15 \%$ & 3 & 0,6 \\
\hline 5 & Kerjasama dan Tim & $10 \%$ & 3 & 0,6 \\
\hline 6 & Pelayanan pada Universitas & $7 \%$ & 1,75 & 0,35 \\
\hline & Total & $100 \%$ & 45,35 & 9,07 \\
\hline
\end{tabular}

\section{Klasifikasi :}

$$
\begin{aligned}
& 09-20=\text { Unsatisfied } \\
& 21-30=\text { Minimal } \\
& 31-40=\text { Competent } \\
& 41-50=\text { Excellent }
\end{aligned}
$$

\section{Hasil Akhir Model Perancangan Evaluasi Diri Dosen}

Tanggal :

Jawablah pertanyaan-pertanyaan dibawah ini.

Pernyataan ini menggunakan tingkat skala, untuk mengukur tingkat evaluasi diri dari :

\begin{tabular}{|c|c|c|c|c|c|c|}
\hline No. & Keterangan & 1 & 2 & 3 & 4 & 5 \\
\hline 1 & $\begin{array}{l}\text { Mempersiapkan presentasi kuliah dan bahan pengajaran (termasuk } \\
\text { cara baru dalam pendekatan dan perencanaan) }\end{array}$ & & & & & \\
\hline 2 & $\begin{array}{l}\text { Mencatat setiap sumber informasi untuk pengetahuan-pengetahuan } \\
\text { baru yang didapatkan }\end{array}$ & & & & & \\
\hline 3 & $\begin{array}{l}\text { Adanya usaha mencari topik-topik terakhir terkait materi } \\
\text { pembelajaran }\end{array}$ & & & & & \\
\hline 4 & $\begin{array}{l}\text { Mempertunjukkan kemampuan mengajar (merumuskan gagasan } \\
\text { dengan jelas dan tepat, dan mempresentasikan ide-ide secara jelas, } \\
\text { memilih penggunaan metoda mengajar secara efektif dan dapat } \\
\text { memeotivasi para siswa)? }\end{array}$ & & & & & \\
\hline 5 & $\begin{array}{l}\text { Penjelasan materi di kelas dilengkapi dengan ringkasan point-point } \\
\text { penting di tiap modul }\end{array}$ & & & & & \\
\hline
\end{tabular}

1 = tidak pernah, 2 = jarang, 3 = cukup $/$ kadang-kadang, 4 = sering, $5=$ selalu

Berilah tanda ( X ) pada kolom yang cukup merepresentasikan diri Anda.

\section{Pembelajaran (30\%)}




\begin{tabular}{|c|l|l|l|l|l|}
\hline 6 & $\begin{array}{l}\text { Menggunakan metode dan starategi pengajaran (contoh: } \\
\text { constructurism) }\end{array}$ & & & & \\
\hline 7 & $\begin{array}{l}\text { Mengkoordinir kelompok diskusi di kelas (menyediakan topik } \\
\text { diskusi untuk mahasiswa) }\end{array}$ & & & & \\
\hline 8 & Menjaga hubungan formal dengan para siswa secara efektif & & & \\
\hline 9 & Mengevaluasi diri sendiri mengenai cara mengajar? & $\begin{array}{l}\text { Menyelesaikan tugas-tugas administratif mengajar (contoh: absensi, } \\
\text { pengisian buku monitoring, dan lain-lain). }\end{array}$ & & & \\
\hline 11 & $\begin{array}{l}\text { Kesediaan mengadakan waktu untuk diskusi materi pembelajaran } \\
\text { dengan mahasiswa di luar jam pelajaran di dalam lingkungan } \\
\text { kampus. }\end{array}$ & & & & \\
\hline 12 & Objektif dalam memberikan nilai & & & \\
\hline
\end{tabular}

\section{Saran:}

Profesionalisme (20\%)

\begin{tabular}{|c|c|c|c|c|c|c|}
\hline No. & Keterangan & 1 & 2 & 3 & 4 & 5 \\
\hline 1 & $\begin{array}{l}\text { Memiliki sumber bahan yang up to date terkait materi perkuliahan } \\
\text { yang diajarkan (misalnya, jurnal, anggota milling list profesional) }\end{array}$ & & & & & \\
\hline 2 & Kebanggaan sebagai seorang dosen. & & & & & \\
\hline 3 & $\begin{array}{l}\text { Senantiasa menimbah/mengikuti perkembangan ilmu terkait (Life } \\
\text { Long Learning) }\end{array}$ & & & & & \\
\hline 4 & $\begin{array}{l}\text { Dapat mengorganisasikan diri sendiri, melakukan pengarsipan } \\
\text { catatan yang tertulis }\end{array}$ & & & & & \\
\hline 5 & $\begin{array}{l}\text { Menunjukkan kehadiran yang baik, ketersediaan, dan ketepatan } \\
\text { waktu dalam bekerja? }\end{array}$ & & & & & \\
\hline 6 & Dapat mengatur waktu secara efektif & & & & & \\
\hline 7 & Menunjukkan suatu komitmen kerja sebagai dosen & & & & & \\
\hline 8 & Memperlihatkan integritas pribadi, tenggang rasa, dan kejujuran & & & & & \\
\hline 9 & Menyadari pentingnya riset, pengajaran, kebebasan akademis & & & & & \\
\hline 10 & Merasa memiliki atau menjadi bagian dari Universitas & & & & & \\
\hline 11 & Mengerti peraturan, menghormati kode etik dosen & & & & & \\
\hline 12 & Mendukung nilai (values) yang diterapkan di Universitas & & & & & \\
\hline 13 & $\begin{array}{l}\text { Membantu perkembangan reputasi Universitas dan unit } \\
\text { organisasinya }\end{array}$ & & & & & \\
\hline
\end{tabular}

\section{Saran:}


Penelitian (20\%)

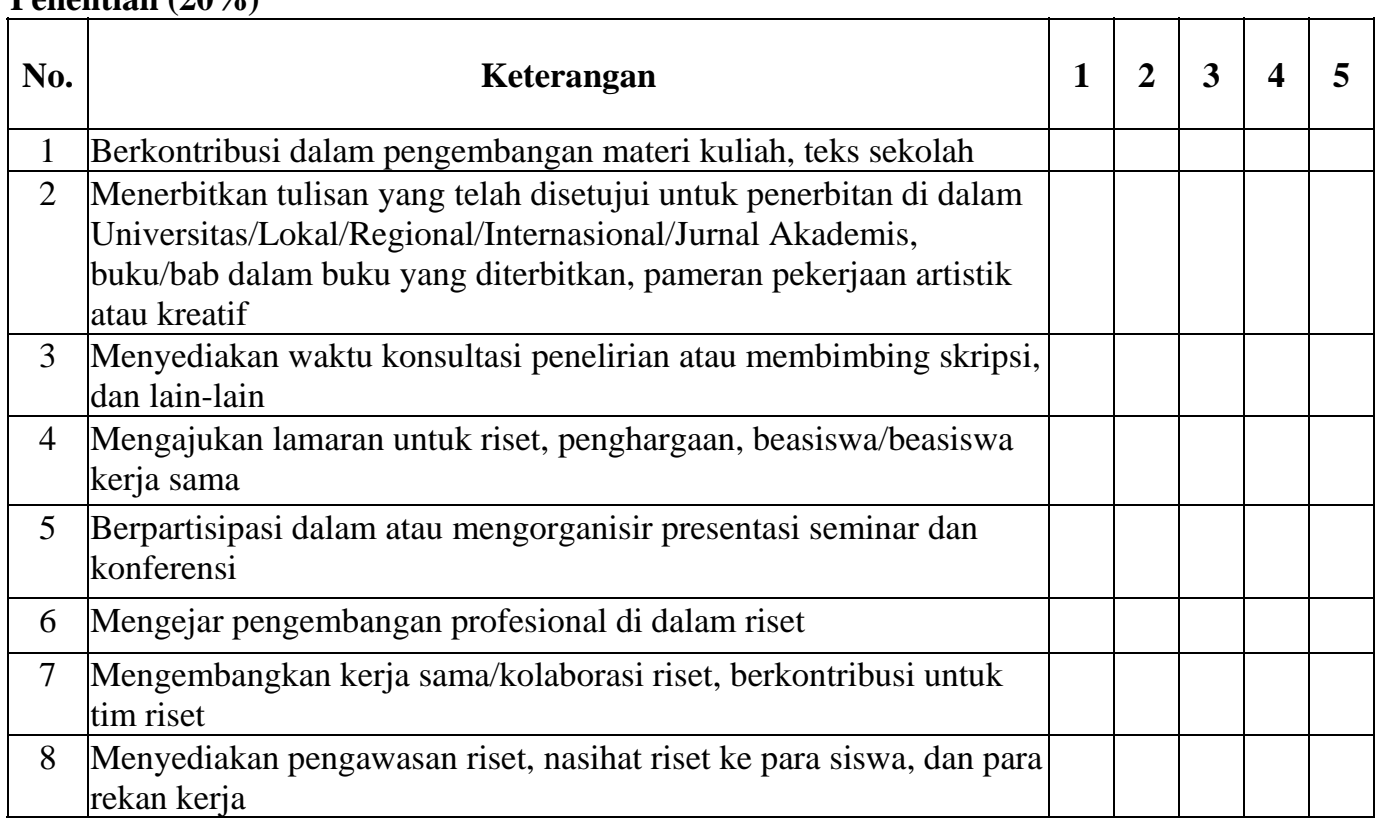

\section{Saran:}

Teknologi dan Komputerisasi (15\%)

\begin{tabular}{|c|c|c|c|c|c|}
\hline No. & Keterangan & 1 & 2 & 3 & 4 \\
\hline 1 & $\begin{array}{l}\text { Menyampaikan informasi kepada kelas atau kelompok } \\
\text { menggunakan aplikasi program komputer, seperti Word Processor, } \\
\text { Excel, atau Power Point }\end{array}$ & & & & \\
\hline 2 & Mengikuti pelatihan program komputer yang diadakan oleh LRC & & & & \\
\hline 3 & $\begin{array}{l}\text { Menfasilitasi mahasiswa dengan menggunakan berbagai macam } \\
\text { aplikasi komputer untuk mempresentasikan penelitian, mencari } \\
\text { informasi yang berhubungan dengan masalah atau materi kuliah } \\
\text { yang sedang mereka pelajari. }\end{array}$ & & & & \\
\hline 4 & $\begin{array}{l}\text { Menghasilkan materi kuliah dalam bentuk multimedia (video, audio, } \\
\text { animasi, dan lain-lain) }\end{array}$ & & & & \\
\hline
\end{tabular}

\section{Saran:}




\begin{tabular}{|c|c|c|c|c|c|c|}
\hline No. & Keterangan & 1 & 2 & 3 & 4 & 5 \\
\hline 1 & $\begin{array}{l}\text { Dapat bekerja sama dan berkolaborasi dengan orang yang lain } \\
\text { dalam mencapai tujuan Universitas dan Jurusan. }\end{array}$ & & & & & \\
\hline 2 & Kesediaan berbagai pengetahuan dan informasi dengan dosen lain. & & & & & \\
\hline 3 & $\begin{array}{l}\text { Mempertimbangkan pandangan orang lain dan melibatkan rekan } \\
\text { kerja dalam pengambilan keputusan. }\end{array}$ & & & & & \\
\hline 4 & $\begin{array}{l}\text { Mencari konsensus dan solusi sama-sama menguntungkan terhadap } \\
\text { masalah dan konflik }\end{array}$ & & & & & \\
\hline 5 & $\begin{array}{l}\text { Membangun dan memelihara hubungan kerja dalam kelompok dan } \\
\text { lingkungan sekitar }\end{array}$ & & & & & \\
\hline 6 & $\begin{array}{l}\text { Apakah mendukung dengan aktif dan mengambil bagian secara } \\
\text { penuh dan berinisiatif di dalam kelompok dan berbagai pertemuan. }\end{array}$ & & & & & \\
\hline
\end{tabular}

Saran:

Pelayanan pada Universitas (5\%)

\begin{tabular}{|c|c|c|c|c|c|c|}
\hline No. & Keterangan & 1 & 2 & 3 & 4 & 5 \\
\hline 1 & Mendukung dan mempromosikan institusi dan unit organisasi & & & & & \\
\hline 2 & $\begin{array}{l}\text { Menyediakan aktivitas jasa layanan kepada unit organisasi, fakultas, } \\
\text { perguruan tinggi atau Universitas (contoh: mendatangkan dosen } \\
\text { tamu, menyelenggarakan seminar, dan lain-lain ) }\end{array}$ & & & & & \\
\hline 3 & $\begin{array}{l}\text { Menyediakan waktu untuk nasehat/konsultasi/mentoring untuk } \\
\text { pengembangan Universitas/Unit Organisasi jika diminta }\end{array}$ & & & & & \\
\hline 4 & Duduk dalam komite (di dalam atau di luar) Universitas jika diminta & & & & & \\
\hline 5 & Memberikan informasi mengenai peluang di luar Universitas & & & & & \\
\hline 6 & Melakukan pengabdian masyarakat yang diadakan oleh Universitas & & & & & \\
\hline
\end{tabular}

\section{Saran:}




\section{PENUTUP}

Simpulan yang diperoleh berdasarkan penelitian sebagai berikut. Pertama, variabel yang digunakan untuk perancangan evaluasi dosen adalah Pembelajaran (Bobot $30 \%$ ), jumlah variabel 12; Profesionalisme (Bobot 21\%), jumlah variabel 13; Penelitian (Bobot 17\%), jumlah variabel 8; Teknologi dan Komputerisasi (Bobot 15\%), jumlah variabel 4; Kerja sama dan Tim (Bobot 10\%), jumlah variabel 6; Pelayanan pada Universitas (Bobot 7\%), jumlah variabel 6.

Kedua, model evaluasi diri dosen ini baru merupakan model awal yang masih harus diperbaiki dan diteliti lebih lanjut. Ketiga, model evaluasi diri dosen ini dapat juga digunakan sebagai acuan bagi para dosen untuk mendapatkan kondisi yang ideal sebagai seorang dosen. Keempat, pada variabel kerja sama dalam tim dan pelayanan pada universitas, akan menjadi hambatan bagi dosen tidak tetap dan dosen staf untuk mendapatkan angka kredit yang tinggi karena kesibukan mereka sehingga hanya khusus mengajar di kelas saja.

Saran untuk penelitian selanjutnya, yaitu keberhasilan dari proses evaluasi diri dosen ini sangat tergantung pada kejujuran dan objektivitas responden. Masih ada variabel lain yang mungkin dapat dimasukan dalam model evaluasi diri dosen, misalnya Hubungan dengan universitas luar negeri. Model ini hanya berlaku untuk dosen Universitas Bina Nusantara, belum merupakan model nasional yang dapat diterapkan pada universitas di seluruh Indonesia sehingga hal ini dapat dijadikan untuk penelitian lainnya.

\section{DAFTAR PUSTAKA}

Dressler, Gary. 2003. Human Resource Management. $9^{\text {th }}$ Edition. Prentice Hall.

Evans, Lindsay. 2002. The Management and Control of Quality. $5^{\text {th }}$ Edition. Thompson Learning.

McNiff, Jean. 1995. Action Research for Professional Development. 11th Edition. Hyde Publication, UK.

Seldin, P. 1984. Changing Practices in Faculty Evaluation. San Francisco: Jossey-Bass.

Tampubolon, Daulat P. 2001. Perguruan Tinggi Bermutu: Paradigma Baru Manajemen Pendidikan Tinggi Menghadapi Tantangan Abad 21. Jakarta: PT Gramedia Pustaka Utama.

University of Sydney. Annual Activities Evaluation (AAE) Form. 2001. 